\title{
Pengaruh Transfusi Trombosit Terhadap Terjadinya Perdarahan Masif pada Demam Berdarah Dengue
}

\author{
Krisnanto Wibowo, Mohammad Juffrie, Ida S. Laksanawati, Sri Mulatsih \\ Bagian Ilmu Kesehatan Anak, Fakultas Kedokteran Universitas Gadjah Mada - Rumah Sakit Dr. Sardjito, \\ Yogyakarta
}

\begin{abstract}
Latar belakang. Perdarahan masif merupakan salah satu komplikasi dan berhubungan dengan mortalitas yang tinggi pada demam berdarah dengue (DBD). Pemberian transfusi trombosit pada DBD merupakan terapi suportif yang memberikan efek terapi bila diberikan sesuai dengan indikasi yang tepat. Kegunaan transfusi trombosit masih kontroversial.

Tujuan. Mengetahui pengaruh pemberian transfusi trombosit terhadap terjadinya perdarahan masif pada DBD.

Metode. Penelitian merupakan penelitian kasus kontrol. Pasien dengan diagnosis DBD sesuai kriteria WHO yang dirawat di instalasi kesehatan anak RSUP Dr.Sardjito tahun 2006-2009 diteliti dari rekam medis. Kasus adalah pasien dengan perdarahan masif, sedangkan kontrol adalah pasien dengan perdarahan tidak masif.

Hasil. Sepanjang tahun 2006-2009 terdapat 852 kasus DBD, terdiri dari 443 laki-laki (52\%), 409 perempuan (48\%), dan 35,7\% adalah pasien DBD derajat II. Perdarahan masif terjadi pada 97 kasus (11\%) yaitu hematemesis 45 (46,4\%), melena 20 (20,6\%), hematemesis-melena 25 (25,8\%), dan koagulasi intravaskular diseminata $7(8,2 \%)$. Perdarahan masif terbanyak terjadi pada jumlah trombosit $<20.000 / \mu \mathrm{L}$. Sebanyak 67 pasien $(7,8 \%)$ mendapat transfusi trombosit, 23 pada kelompok kasus dan 44 pada kelompok kontrol. Tidak ada perbedaan bermakna terjadinya perdarahan masif pada kedua kelompok tersebut (rasio odds 1,39; interval kepercayaan 95\% 0,79-2,45; p=0,29).

Kesimpulan. Terjadinya perdarahan masif tidak dipengaruhi oleh transfusi trombosit.

Sari Pediatri 2011;12(6):404-8.
\end{abstract}

Kata kunci: demam berdarah dengue, perdarahan masif, transfusi trombosit

\footnotetext{
Alamat korespondensi:

Dr. Ida Safitri Laksanawati, Sp.A. Bagian Ilmu Kesehatan Anak Fakultas Kedokteran Universitas Gadjah Mada - Rumah Sakit Dr. Sardjito Yogyakarta, Jl. Kesehatan no 1, Yogyakarta, Indonesia. Telp. 0274561616. Fax: 0274-583745.
}

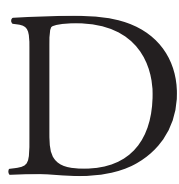
emam berdarah dengue (DBD) merupakan penyakit demam akut yang disebabkan oleh empat serotipe virus dengue yaitu DEN 1, 2, 3, dan 4 dengan morbiditas dan mortalitas yang tinggi di banyak daerah di dunia. Virus dengue dapat menyebabkan manifestasi klinis yang bermacam-macam dari asimtomatik sampai fatal. ${ }^{1}$ 
Pada dasarnya tata laksana DBD bersifat suportif yaitu mengatasi kehilangan cairan plasma sebagai akibat peningkatan permeabilitas kapiler dan sebagai akibat perdarahan. Manifestasi perdarahan adalah salah satu komplikasi yang ditakuti dan berhubungan dengan mortalitas yang tinggi pada DBD. Sejak diperkenalkannya transfusi trombosit dalam tata laksana DBD, indikasi pasti dan pada situasi apa transfusi trombosit ini diberikan masih bervariasi. Belum ada panduan yang jelas tentang pemberian transfusi trombosit. Keputusan pemberian transfusi trombosit selama ini masih tergantung dari pengalaman para klinisi dan ketersediaan komponen trombosit. Kekhawatiran yang berlebihan terhadap terjadinya syok dan perdarahan pada pasien DBD, menyebabkan praktek pemberian transfusi komponen darah sering dilakukan secara berlebihan. Banyak dokter memberikan transfusi demi menghindari kepanikan bukan berdasarkan standar pelayanan medis. ${ }^{2}$ Kumar $\mathrm{dkk}^{3}$ melaporkan bahwa 35\% pasien dengue mendapatkan profilaksis transfusi trombosit yang tidak perlu dan $89 \%$ dari pasien tersebut mendapat dosis transfusi yang tidak tepat.

Penelitian bertujuan untuk mengetahui pengaruh transfusi trombosit terhadap terjadinya perdarahan masif pada pasien DBD. Dari hasil penelitian ini diharapkan dapat dijadikan pertimbangan dalam menentukan perlu tidaknya pemberian transfusi trombosit dalam tata laksana DBD.

\section{Metode}

Rancang bangun penelitian adalah kasus kontrol dari data rekam medis pasien yang dirawat di Instalasi Kesehatan Anak RSUP Dr.Sardjito selama tahun 2006-2009. Kasus adalah pasien dengan perdarahan masif, meliputi hematemesis, melena, hematemesis dan melena, serta koagulasi intravaskular diseminata (KID), sedangkan kontrol adalah pasien dengan perdarahan lain yang tidak masif meliputi petekiae, epistaksis, dan perdarahan gusi.

Subyek penelitian ditentukan berdasarkan kriteria inklusi yaitu pasien DBD sesuai kriteria WHO 1997, berumur <18 tahun, dan didapat tanda tangan persetujuan dirawat. Kriteria eksklusi yaitu data rekam medis yang tidak lengkap. Besar sampel ditentukan berdasarkan rumus uji hipotesis terhadap rasio odds. ${ }^{4}$ Variabel bebas adalah transfusi trombosit dan tanpa transfusi trombosit, sedangkan variabel tergantung adalah perdarahan masif dan perdarahan tidak masif.

Analisis data univariat pada penelitian menggunakan uji chi square. Nilai untuk ukuran risiko (odds ratio/OR) dihitung dengan interval kepercayaan 95\% (95\% CI).

\section{Hasil}

Selama periode penelitian didapatkan 852 kasus DBD yang dirawat di Instalasi Kesehatan Anak RSUP Dr. Sardjito, Yogyakarta. Dari sejumlah kasus tersebut (Tabel 1), anak laki-laki lebih banyak yang menderita DBD (52\%) dibanding anak perempuan (48\%), dan kelompok usia 6-10 tahun adalah kelompok umur paling tinggi dibandingkan dengan kelompok usia lain, diikuti kelompok usia $>11$ tahun $(27,4 \%)$, dan hanya $<10 \%$ anak usia kurang dari satu tahun yang menderita DBD. Berdasarkan derajatnya, DBD derajat I merupakan yang terbanyak $(51,4 \%)$, kemudian DBD derajat II $(35,7 \%)$, sedangkan yang dirawat dengan syok $12,9 \%$.

Tabel 1. Karakteristik pasien

\begin{tabular}{lc}
\hline Karakteristik & $\mathrm{n}=852(\%)$ \\
\hline $\begin{array}{l}\text { Jenis kelamin, n (\%) } \\
\quad \text { Laki-laki } \\
\quad \text { Perempuan }\end{array}$ & $443(52)$ \\
$\begin{array}{l}\text { Umur, (tahun, n (\%)) } \\
\quad 1\end{array}$ & $409(48)$ \\
$\quad 1-5$ & $82(9,6)$ \\
6-10 & $197(23,1)$ \\
$\quad>11$ & $340(39,9)$ \\
Derajat DBD, n (\%) & $233(27,4)$ \\
$\quad$ derajat I & \\
$\quad$ derajat II & $438(51,4)$ \\
$\quad$ derajat III & $304(35,7)$ \\
\hline
\end{tabular}

Tabel 2. Kejadian perdarahan masif

\begin{tabular}{lcc}
\hline Perdarahan masif & $\mathrm{n}$ & $\%$ \\
\hline Hematemesis & 45 & 46,4 \\
Melena & 20 & 20,6 \\
Hematemesis + melena & 25 & 25,8 \\
KID & 7 & 7,2 \\
\hline Jumlah & 97 & 100 \\
\hline
\end{tabular}


Krisnanto Wibowo dkk: Pengaruh transfusi trombosit terhadap terjadinya perdarahan masif pada demam berdarah dengue

Tabel 3. Jumlah trombosit dan kejadian perdarahan masif

\begin{tabular}{lccccccc}
\hline Jumlah trombosit $10^{3} \mathrm{vol} \%$ & Total & $\mathrm{H}$ & $\mathrm{M}$ & $\mathrm{H}+\mathrm{M}$ & $\mathrm{KID}$ & $\mathrm{n}$ & Total \% \\
\hline$<20$ & 62 & 8 & 4 & 3 & 1 & 15 & 24,1 \\
$>20-50$ & 327 & 15 & 8 & 14 & 4 & 40 & 12,2 \\
$>50-100$ & 463 & 22 & 8 & 8 & 2 & 39 & 8,4 \\
$>100$ & 0 & - & - & - & - & - & - \\
\hline Jumlah & 852 & 45 & 20 & 25 & 7 & 97 & 11,0 \\
\hline
\end{tabular}

H: Hematemesis, M: Melena, H+M: Hematemesis dan Melena, KID: Koagulasi intravaskular diseminata

Tabel 4. Hubungan derajat DBD dengan perdarahan masif

\begin{tabular}{|c|c|c|c|c|c|c|}
\hline \multirow{2}{*}{ Derajat DBD } & \multicolumn{2}{|c|}{ Perdarahan Masif } & \multirow{2}{*}{$\mathrm{n}$} & \multirow{2}{*}{ OR } & \multirow{2}{*}{ CI } & \multirow{2}{*}{ P } \\
\hline & $\mathrm{Ya}$ & Tidak & & & & \\
\hline SSD & 34 & 76 & 110 & 1,71 & $(1,05-2,79)$ & 0,031 \\
\hline DBD II & 63 & 241 & 304 & & & \\
\hline Jumlah & 97 & 317 & 414 & & & \\
\hline
\end{tabular}

Tabel 5. Hubungan antara kejadian perdarahan masif dengan transfusi trombosit

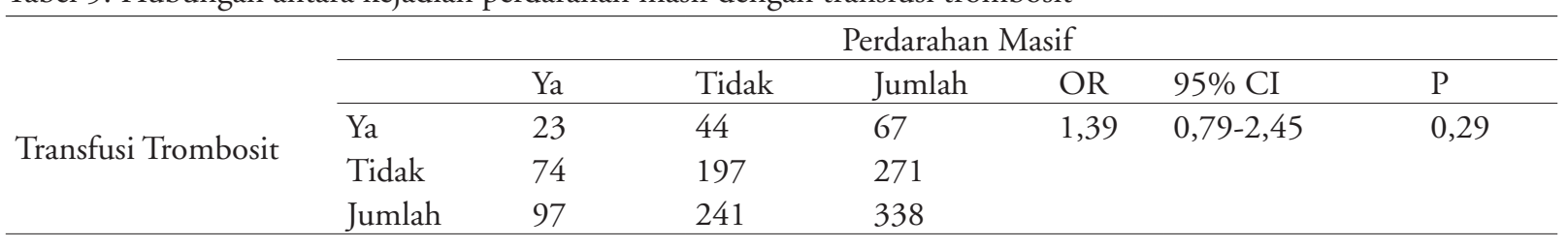

Dari keseluruhan kasus DBD, terdapat 97 kasus (11\%) dengan kriteria perdarahan masif, yaitu hematemesis $46,4 \%$, melena $20,6 \%$, hematemesismelena 25,8\%, dan KID 8,2\%.

Tabel 3 menunjukkan persentase perdarahan masif berdasarkan jumlah trombosit paling tinggi terjadi pada pasien dengan jumlah trombosit $<20,000 / \mu$, sebesar $24 \%$.

Tabel 4 menunjukkan pasien SSD lebih banyak yang mengalami perdarahan masif, hampir dua kali lipat bila dibandingkan dengan pasien DBD derajat II (OR 1,71; 95\%CI 1,05-2.79; $\mathrm{p}=0,031)$. Dari 852 subyek penelitian, 67 pasien $(7,9 \%)$ mendapat transfusi trombosit terdiri atas 23 pada kelompok dengan perdarahan masif (kasus) dan 44 pada kelompok perdarahan tidak masif (kontrol).

Hubungan antara kejadian perdarahan masif dengan transfusi trombosit menunjukkan bahwa transfusi trombosit tidak mempengaruhi terjadinya perdarahan masif (OR 1.39; 95\%CI: 0.79-2.45; $\mathrm{p}=0.29)$ (Tabel 5).

\section{Pembahasan}

Demam berdarah dengue hingga kini masih merupakan masalah kesehatan masyarakat yang serius di Indonesia. Insidens kasus DBD yang dirawat di Instalasi Kesehatan Anak Rumah Sakit Dr. Sardjito cukup tinggi, dan dijumpai sepanjang tahun. Peningkatan kasus rawat ini kemungkinan karena kejadian DBD di masyarakat cukup tinggi, kekhawatiran petugas kesehatan di lapangan sehingga menyarankan pemeriksaan laboratorium, ataupun karena ketakutan masyarakat terhadap bahaya penyakit DBD. Selain itu kemungkinan disebabkan diagnosis berlebihan karena kriteria kasus DBD dibuat cukup longgar. Citraresmi $\mathrm{dkk}^{5}$ dalam penelitiannya menyebutkan, jika dibandingkan diagnosis saat pulang, pasien DBD tanpa syok dan DBD dengan syok sesuai diagnosis menurut kriteria WHO 1997, ternyata pada saat pulang hanya $19,1 \%$ pasien yang didiagnosis DBD tanpa syok sesuai dengan kriteria WHO 1997, sedangkan DBD dengan syok, 99\% memiliki kesesuaian diagnosis dengan kriteria WHO 1997. 
Penelitian kami menunjukkan mayoritas kasus DBD pada anak terjadi pada usia 6-10 tahun (usia sekolah dasar). Hasil tersebut hampir sama dengan penelitian Siregar ${ }^{6}$ yang mendapatkan bahwa kasus DBD lebih banyak terjadi pada anak usia 5-10 tahun. Anak-anak prasekolah atau sekolah dasar (usia 4-12 tahun) seringkali menunjukkan respon serologi sekunder disebabkan serotipe virus heterolog. Jumlah kasus DBD terbanyak dan spesimen otopsi didapat dari golongan usia sekolah. ${ }^{7}$ Informasi tersebut sangat berguna dalam menentukan tindakan pencegahan. Pengetahuan terhadap kelompok usia yang paling berisiko akan menentukan kebijakan pencegahan.

Anak laki-laki memiliki angka kesakitan yang lebih tinggi dibanding anak perempuan, tetapi pada dasarnya tidak ada perbedaan dalam hal jenis kelamin terhadap angka kesakitan DBD. ${ }^{8}$ Meskipun hasil penelitian lain menunjukkan pola kejadian yang sama.

Perdarahan masif lebih sering terjadi pada pasien dengan trombositopenia berat dan paling sering pada jumlah trombosit kurang dari 20.000/ $\mathrm{LL}$. Sesuai dengan penelitian yang dilakukan oleh Makroo $\mathrm{dkk},{ }^{9}$ sedangkan Chairulfatah $\mathrm{dkk}^{10}$ mendapatkan perdarahan masif lebih sering didapatkan pada jumlah trombosit $<15.000 / \mu \mathrm{L}$. Chaudhary $\mathrm{dkk}^{11}$ mendapatkan hasil bahwa tidak ada hubungan antara timbulnya perdarahan dengan jumlah trombosit bahkan pada trombositopenia berat $(<20.000 / \mu \mathrm{L})$. Beberapa peneliti melaporkan, penurunan kadar trombosit yang drastis pada pasien DBD bukan prediktor perdarahan, namun ada faktor lain seperti disfungsi trombosit, vaskulopati, dan koagulopati yang memegang peran dalam terjadinya perdarahan. ${ }^{12}$

Pasien dengan SSD pada penelitian kami lebih banyak yang mengalami perdarahan masif dibandingkan pasien DBD. Hasil tersebut hampir sama dengan penelitian Petdachai ${ }^{14}$ di Thailand. Kecenderungan untuk terjadinya perdarahan disebabkan oleh terjadinya penggunaan fibrinogen secara berlebihan dan memendeknya waktu paruh fibrinogen selama syok berlangsung. Hal tersebut ditunjang oleh hasil penelitian di Indonesia yang mengungkapkan bahwa pada SSD dijumpai trombositopenia, penurunan kadar fibrinogen dan faktor VIII, serta peningkatan fibrin degradation product (FDP). Koagulopati akan lebih sering terjadi pada kebocoran plasma yang berat. Penurunan faktor koagulasi mungkin merupakan hasil peningkatan konsumsi intravaskular atau gangguan sintesis di hepar. ${ }^{12,14}$
Hingga saat ini belum ada kesamaan sikap tentang kapan sebaiknya transfusi trombosit diberikan. Penelitian sebelumnya memberikan batasan yang bervariasi mengenai hal ini. Di Singapura, indikasi untuk transfusi trombosit adalah angka trombosit (AT) $<10.000 / \mathrm{mm}^{3}$ pada pasien yang stabil, $<20.000 / \mathrm{mm}^{3}$ dengan perdarahan minor, dan $50.000 / \mathrm{mm}^{3}$ dengan perdarahan yang signifikan. ${ }^{13}$ Pada penelitian kami $7,8 \%$ mendapat transfusi trombosit. Hubungan antara kejadian perdarahan masif dengan transfusi trombosit menunjukkan bahwa transfusi trombosit tidak mempengaruhi terjadinya perdarahan masif. Penelitian sebelumnya oleh Makroo dkk ${ }^{9}$ dan Chairulfatah $\mathrm{dkk}^{10}$ menunjukkan hasil yang sama. Hasil penelitian kami membuktikan trombositopenia tidak sendiri dalam menyebabkan perdarahan, namun bersama mekanisme lain trombositopenia berperan pada terjadinya perdarahan pada DBD yaitu vaskulopati, koagulopati, dan trombopati. Risiko perdarahan masif pada pasien DBD berdasarkan laporan Lum $\mathrm{dkk}^{15}$ dipengaruhi oleh durasi syok dan rendahnya hematokrit saat terjadinya syok. Pasien tidak memerlukan transfusi trombosit dan tidak mengalami perdarahan masif apabila syok ditangani secara adekuat. Transfusi trombosit pada penelitian kami berhubungan dengan rawat inap yang lebih lama dan peningkatan kejadian kelebihan (overload) cairan.

Disimpulkan tidak ada perbedaan dalam terjadinya perdarahan masif pada kelompok yang mendapat transfusi trombosit maupun yang tidak mendapat transfusi, berarti transfusi trombosit tidak mempengaruhi kejadian perdarahan masif pada DBD. Pemberian transfusi trombosit yang tidak sesuai indikasi sangat merugikan dalam banyak hal antara lain beban ekonomi, reaksi transfusi, serta penularan penyakit sehingga pemberian transfusi trombosit harus tepat indikasi, dan tidak hanya berdasarkan jumlah trombosit.

\section{Daftar pustaka}

1. Halstead SB, penyunting. Dengue: Overview and history. Dalam: Halstead SB. Dengue. London: Imperial College Press; 2008.h. 1-28.

2. Cahyono SB. Pemberian transfusi trombosit pada pasien demam berdarah dengue. Ethical Digest 2007; 38:6670 .

3. Kumar ND, Tomar V, Singh B, Kela K. Platelet 
transfusion practice during dengue fever epidemic. Indian J Pathol Microbiol 2000; 43:55-60.

4. Madiyono B, Moezlichan S, Sastroasmoro S, Budiman I, Purwanto SH. Perkiraan besar sampel. Dalam: Sastroasmoro S, Ismael S, penyunting. Dasar-dasar metodologi penelitian klinis. Edisi kedua. Jakarta: Sagung Seto; 2002.h. 259-86.

5. Citraresmi E, Hadinegoro SR, Akib AAP. Diagnosis dan tata laksana demam berdarah dengue pada kejadian luar biasa tahun 2004 di enam rumah sakit di Jakarta. Sari Pediatri 2007; 8:8-14.

6. Siregar AD. Gambaran pasien berdarah dengue di bangsal anak RSUD Dr. Abdul Aziz Singkawang tahun 2005. Dexa Media 2006; 2:66-71.

7. Bhamarapravati N. Pathology of dengue infections. Dalam: Gubler DJ, Kuno G, penyunting. Dengue and dengue hemmorhagic fever. London: CAB International; 1997.h. 115-32.

8. Kuno G. Factors influencing the transmission of dengue viruses. Dalam: Gubler DJ, Kuno G, penyunting. Dengue and dengue hemmorhagic fever. London: $\mathrm{CAB}$ International; 1997.h. 61-88.

9. Makroo RN, Raina V, Kumar P, Kanth RK. Role of platelet transfusion in the management of dengue patients in a tertiary care hospital. Asian J Transf Sci 2007; 1:4-7.

10. Chairulfatah A, Setiabudi D, Agoes R, Colebunders R. Thrombocytopenia and platelet transfusion in dengue hemorrhagic fever and dengue shock syndrome. Dengue Bulletin 2003; 27:138-43.

11. Chaudhary R, Khetan D, Ray V. Transfusion support to dengue patients in a hospital based blood transfusion service in North India. Transfus Apher Sci 2006; 35:23944.

12. Chuansumrit A, Phimolthares V, Tardtong P, Tapaneya OC, Kowsathit P, Chantarojsiri T. Transfusion requirement in patients with dengue hemorrhagic fever. Southeast Asian J Trop Med Public Health 2000; 31:10-4.

13. Teik OC. A guide to DHF/DSS management-the Singapore experience. Dengue Bulletin 2001; 25:45-9.

14. Petdachai W. Hepatic dysfunction in children with dengue shock syndrome, Dengue Bulletin 2005; 25:112-8.

15. Lum S, Latief A, Goh T, Chan K, Lam SK. Preventive transfusion in dengue shock syndrome-is it necessary? J Pediatr 2003; 143:682-4. 